\title{
Sykepleiere kan gjøre maskebehandling bedre med enkle tiltak
}

\section{Maskebehandling kan gi pasienter med pustebesvær klaustrofobi, trykksår og andre former for ubehag. Sykepleiere kan forebygge og lindre, og på den måten optimalisere behandlingen.}

\section{Gunhild Bekkevold Larsen}

Intensivsykepleier

Intensiv og postoperativ avdeling, Sykehuset Østfold, Kalnes

Ann-Chatrin Linqvist Leonardsen

Førsteamanuensis

Sykehuset Østfold og Høgskolen i Østfold

Respirasjon

Sykepleie-pasient-forhold

Intensivsykepleie

\section{Hovedbudskap}

Respirasjonsbesvær er et hyppig forekommende symptom hos pasienter, som ofte også fører til angst. Ved respirasjonsbesvær har pasientene behov for ventilasjonsst $\varnothing$ ttende tiltak for å lindre symtpomene og bedre oksygeneringen. Non-invasiv ventilasjonsbehandling (NIV), også kalt maskebehandling, er en behandlingsform som tilbys både i kommunehelsetjenesten og på sykehus. Denne fagartikkelen s $\varnothing$ ker å belyse hvordan sykepleiere kan bidra til optimal maskebehandling. 
Respirasjonsbesvær er et hyppig forekommende symptom hos pasienter både i kommunehelsetjenesten og på sykehus, og forekomsten er $\varnothing$ kende (1-3). I tillegg er dette et symptom som i stor grad fører til angst hos pasientene (4-6).

Respirasjonsbesvær kan gjenspeile sykdom i lunger eller hjerte- og karsystemet eller andre systemiske tilstander som anemi (7).

Ved respirasjonsbesvær har pasientene ofte behov for ventilasjonsst $\varnothing t t e n d e$ tiltak for å lindre symptomene, og bedre oksygeneringen. Non-invasiv ventilasjonsbehandling (NIV), også kalt maskebehandling, er en behandlingsform som tilbys både i kommunehelsetjenesten og på sykehus. Denne fagartikkelen søker å belyse hvordan sykepleiere kan bidra til optimal maskebehandling.

\section{Hva er non-invasiv ventilasjonsbehandling?}

Non-invasiv ventilasjonsbehandling (NIV) innebærer at ventilasjonsbehandlingen foregår uten at pasienten blir intubert. Ulemper ved intubasjon er blant annet ventilatorassosiert pneumoni (VAP), vanskelig avvenning fra respirator og lange sykehusopphold (9).

NIV administreres via en tettsittende maske som dekker enten munn og nese, bare nese eller hele ansiktet - derav benevnelsen «maskebehandling». Effekten av NIV er at opplevelsen av tungpust (dyspné) reduseres, respirasjonsarbeidet blir lettere for pasienten, og gassutvekslingen i lungene forbedres (9).

«Continous Positive Airway Pressure» (CPAP) og «Biphasic Positive Airway Pressure» (BiPAP) er to ulike tilnærminger ved bruk av NIV. CPAP gir pasienten ett kontinuerlig positivt luftveistrykk.

\section{$\equiv \ll$ Pasienten puster mot et høyt trykk hele tiden.»}

Pasienten puster altså mot et høyt trykk hele tiden. Dette gjør at diffusjonsoverflaten i lungene $\varnothing \mathrm{kes}$, og shunting reduseres. Lungeshunt er at oksygenfattig blandet veneblod passerer gjennom lungene uten å ta opp nytt oksygen.

Lungenes evne til å endre volum ved trykkforandringer, lungecompliance, blir bedre når man benytter CPAP og BiPAP, og det fører til at pustearbeidet blir lettere. 
CPAP brukes primært ved oksygeneringsproblemer, hypoksi. BiPAP tilfører to positive luftveistrykk: både på inspirasjon (IPAP) og ekspirasjon (EPAP). BiPAP benyttes primært til pasienter med hyperkapni (høyt $\mathrm{CO}_{2}$ i blodet), eventuelt med hypoksi i tillegg (10).

PEEP, også kalt EPAP, er sentralt i NIV-behandlingen og står for positivt endeekspiratorisk trykk. Dette betyr at respirasjonssyklusen starter og slutter med et positivt trykk inne i lungene (9).

Pasienter som skal ha NIV-behandling, må til dels være våkne samt i stand til å holde frie luftveier selv. Blodsirkulasjonen til pasienten bør være stabil fordi overtrykksventilering som oftest senker blodtrykket. Det er flere kontraindikasjoner til NIV. For eksempel er NIV kontraindisert til pasienter med ventrikkelretensjon (fare for aspirasjon) eller til pasienter med ansiktsskader (9).

\section{三 «NIV-behandling er førstevalget når oksygenbehandling ikke hjelper pasienten tilstrekkelig.»}

Ved NIV-behandling er det flere ulike forhold som kan bidra til å optimalisere behandlingen. Erfaringsmessig ønsker man å utsette intubasjon av pasienten så lenge som mulig. NIVbehandling er førstevalget når oksygenbehandling ikke hjelper pasienten tilstrekkelig. Hensikten med denne fagartikkelen er å belyse hvordan sykepleiere kan optimalisere NIV, med hovedvekt på at pasientene skal tolerere behandlingen.

\section{Metode}

Artikkelen avgrenses til å handle om personer over 18 år. Den avgrenses ikke til å gjelde en spesiell diagnose, da respirasjonsbesvær er relevant for flere pasientgrupper.

Litteraturs $\varnothing \mathrm{k}$ ble gjort i PubMed, Medline, Cinahl og SveMed+. Søkeord som ble benyttet, var blant annet «nurse», «critical care nursing», «non-invasive ventilation», «positive pressure ventilation», «breathlessness», «dyspnea», «tolerate», i ulike kombinasjoner med AND/OR.

Artiklene er gjennomgått med sjekklister for kvalitetsvurdering fra Helsebiblioteket, og alle de seks inkluderte artiklene er utgitt i vitenskapelige tidsskrift. 


\section{Slik sørger du for optimal tilpasning}

Ved NIV må masken være tett og uten lekkasjer. Dette innebærer at sykepleieren må gjøre en individuell tilpasning av masken på pasienten. Det er viktig å tilpasse masken slik at man unngår for mye trykk på neseryggen og luftlekkasje (8).

Masketilpasning er erfaringsmessig ikke alltid like lett å få til. Brill og medarbeidere (11) fant at helsepersonell med mer erfaring utførte maskepåsetting med signifikant lavere trykk på neseryggen og mindre luftlekkasje enn personell med mindre erfaring.

\section{$\equiv \ll$ Masketilpasning er erfaringsmessig ikke alltid like lett å få til.»}

Ved oppstart av maskebehandling er det erfaringsmessig ansiktet som initialt vurderes opp mot maskevalg og størrelse. For eksempel hos menn med mye skjegg tenker man gjerne at maskebehandlingen kan gi utfordringer.

Det finnes flere ulike masketyper. Mange avdelinger har tilgang på maskemal, men etter vår erfaring blir denne ikke brukt. Dette støttes blant annet av Sørensen og medarbeidere (12), som fant at sykepleiere valgte maske på intuisjon, basert på et førsteinntrykk.

Vi har erfart at nese-munn-masken er førstevalget i oppstart av NIV. Chacur og medarbeidere (13) fant at pasienter tolererer heldekkende ansiktsmaske signifikant lengre sammenliknet med den tradisjonelle nese-munn-masken. De fant ingen signifikant forskjell på blodgasser eller behov for intubasjon.

Når sykepleier er fornøyd med både type og størrelse av maske, er det ikke sikkert at pasientens kroppsspråk eller ytringer tilsier at pasienten er forn $\varnothing y d$. Da bør sykepleieren vurdere videre om det er andre tiltak som kan gjøres. For eksempel kan dette være å lette på hodestroppene eller løfte litt på masken for å endre leie slik at trykket på neseryggen ikke blir så stort (12).

En erfaring fra praksis viser at trykksår på neserygg og i panne kan lindres med Microfoam (en tykk tape), som er utformet for å avlaste trykk. Dersom ubehaget kommer fra luftlekkasje som affiserer фynene, så ser man dette tydelig om pasienten kniper sammen $\varnothing$ ynene. 
For å identifisere lekkasje fra andre steder på masken må sykepleier bruke hendene for å kjenne etter hvor den eventuelle lekkasjen kommer fra (8).

Andre erfaringsbaserte tips er at hodestroppene kan strammes eller løsnes på. Masken kan også settes på på nytt.

Det kan lønne seg å holde masken foran ansiktet til pasientene en kort stund for gradvis å venne dem til luftstrømmen fra masken. Dette innebærer altså en systematisk tilnærming inntil pasienten er fornøyd og ventilatoren indikerer at ventileringen utføres optimalt.

\section{Pasienten kan bli redd}

Tettsittende maske kan gi en følelse av klaustrofobi, som kan være vanskelig for pasientene å takle $(9,14)$.

Pasienter har beskrevet det som ubehagelig at en annen holder masken fast foran ansiktet, og at det er plagsomt å føle seg avhengig av en annen (14). Erfaring tilsier at morfin hjelper pasienten i oppstarten av NIV-behandling. Enkelte pasienter har også effekt av morfin intermitterende gjennom behandlingsforløpet.

\section{三 «Tettsittende maske kan gi en følelse av klaustrofobi.»}

Ivaretakelse, tillit og trygghet øker pasientens toleranse for maskebehandlingen.

For å mobilisere styrke til å takle maskebehandling, er det viktig med engasjerte sykepleiere som tar pasienten på alvor. Pasienter har beskrevet at de finner styrke i å kunne holde i en hånd samt få ros og positive tilbakemeldinger fra personalet (14).

\section{Samarbeid er viktig}

Samarbeid er viktig for hvordan sykepleier klarer å hjelpe pasienten til å tolerere masken. Toleranse handler om hvorvidt pasienten takler maskebehandlingen eller ikke. 
Samarbeidet mellom pasient og sykepleier har som mål at både pasient og sykepleier jobber for at NIV-behandlingen skal fungere optimalt. Når man får til et godt samarbeid med pasientene, er vår erfaring at sykepleierne ofte klarer å få dem til å tolerere ubehaget av masken. De fleste pasienter forstår alvoret med deres respirasjonsbesvær, og at NIV-masken skal hjelpe dem å lindre dette $(9,10)$.

\section{三 «Når man får til et godt samarbeid med pasientene, er vår erfaring at sykepleierne ofte klarer å få dem til å tolerere ubehaget av masken.»}

Om pasienten vil tolerere masken er avhengig av at pasienten opplever velvære og optimal behandlingseffekt. Å lindre pasientens eventuelle ubehag innebærer at sykepleier iverksetter tiltak med utgangspunkt i hva pasienten selv uttrykker, enten verbalt eller nonverbalt (12). Likevel bør sykepleieren kanskje ikke la pasienten få snakke om «irrelevante plager» når sykepleierens observasjoner, som for eksempel cyanotiske lepper eller økende hypoksi, blir mer og mer tydelige?

Det kan være greit å kartlegge om pasienten har fått NIVbehandling tidligere eller ikke. Selv om pasienten ikke er helt våken, må sykepleieren gi tilstrekkelig med informasjon. Når pasienten våkner til, bør dette repeteres. Ved behov kan det hende at informasjonen må sies flere ganger $(9,10)$.

Når pasienten takler ubehaget fra masken, går behandlingen over til en annen fase, overgangsfasen. I denne fasen settes det opp rutiner, og det fokuseres på proaktiv deltakelse og mobilisering (12).

Å være oppmerksom på pasientens reaksjoner av NIVbehandling er viktig (9). Sykepleierne må aktivt og oppmerksomt styrke pasientenes toleranse for NIV. Sørensen og medarbeidere oppsummerer dette som sanseoppmerksomhet, kroppslig forståelse, beroligende kommunikasjon, kontinuerlige observasjoner, se umiddelbare løsninger, klinisk blikk, oppfølgning av fysiske behov og ubehag, engasjement og oppmuntring, sosiale hensyn og å følge etiske retningslinjer (12). 


\section{Konklusjon}

Enkle tiltak kan $\varnothing$ ke pasientenes toleranse for NIVbehandling. Det er viktig at sykepleier tar seg god tid ved oppstart av maskebehandling. Optimal masketilpasning er også en viktig faktor for å få pasienten til å tolerere NIVbehandlingen.

Godt samarbeid bidrar til å bygge en bro mellom pasient og sykepleier. Ros og oppmuntring under NIV-behandling er viktig for å få pasienten til å mobilisere styrke til å tolerere maskebehandling.

\section{Referanser}

1. Brogger J, Bakke P, Eide GE, Johansen B, Andersen A, Gulsvik A. Long-term changes in adult asthma prevalence. Eur Resp J. 2003;21(3):468-72.

2. Namen AM, Chatterjee A, Huang KE, Feldman SR, Haponik EF. Recognition of sleep apné is increasing. analysis of trends in two large, representative databases of outpatient practice. Ann Am Thorac Soc. 2016;13 (11):2027-34. DOI: $10.1513 /$ AnnalsATS.201603-152OC

3. Villar J, Sulemanji D, Kacmarek RM. The acute respiratory distress syndrome: incidence and mortality, has it changed? Curr Opin Crit Care. 2014;20(1):3-9. DOI: $10.1097 /$ MCC.0000000000000057

4. Haugdahl H, Storli S, Meland B, Dybwik K, Romild U, Klepstad P. Underestimation of patient breathlessness by nurses and physicians during a spontaneous breathing trial. Am J Resp Crit Care Med. 2015;92 (12):1440-8.

5. Puntillo K, Nelson J, Weissman D. Palliative care in the ICU: relief of pain, dyspnoea, and thirst - a report from the IPAL-ICU advisory board. Int Care Med. 2014;4O(2):235-48.

6. Schmidt M, Demoule A, Polito A, Porchet R, Aboab J, Siami S, et al. Dyspnea in mechanically ventilated critically ill patients. Crit Care Med. 2011;39(9):2059-65.

7. Hassett R, Meade K, Partrige M. Enhancing the accuracy of respiratory diagnoses in primary care: a report on the establishment of a Community Respiratory Assessment Unit. Primary Care Resp J. 2006;15(6):354-61. DOI: 10.1016 
8. Bambi S. Noninvasive positive pressure ventilation: an $\mathrm{ABC}$ approach for advanced nursing in emergency departements and acute care settings. Dim Crit Care Nurs. 2009;28(6):253-63. DOI: 10.1097/DCC.obo13e3181b3ffdc

9. Bakkelund J, Thorsen BE. Ikke-invasiv overtrykksventilering. I: Gulbrandsen T, Stubberud DG, red. Intensivsykepleie. Oslo: Cappelen Damm; 2015.

10. Dybwik K. Respiratorbehandling - lærebok for sykepleiere. 2. utg. 1. opplag. Oslo: Gyldendal Akademisk; 2000.

11. Brill AK, Moghal M, Morrell MJ, Simonds AK. Randomized crossover trial of a pressure sensing visual feedback system to improve mask fitting in noninvasive ventilation. Respirology. 2017;22(7):1343-9. DOI:

$\underline{10.1111 / \text { resp.13074 }}$

12. Sørensen D, Frederiksen K, Grøfte T, Lomborg K. Practical wisdom: A qualitative study of the care and management of non-invasive ventilation patients by experienced intensive care nurses. Int Crit Care Nurs. 2013;29(3):174-81. Tilgjengelig fra:

https://www.sciencedirect.com/science/article/pii/So96433971 2000924 (nedlastet 02.02.2019).

13. Chacur FH, Felipe LMV, Fernandes CG, Lazzarini LCO. The total face mask is more comfortable than the oronasal mask in noninvasive ventilation but is not associated with improved outcome. Respiration. 2011;82(5):426-30. DOI: $\underline{10.1159 / 000324441}$

14. Torheim H, Gjengedal E. How to cope with the mask? Experiences of mask treatment in patients with acute chronic obstructive pulmonary diseaseexacerbations. Scand J Caring Sci. 2010;24(3):499-506. DOI: 10.1111/j.1471-6712.2009.00740.x 